\title{
Responsiveness of the Pituitary-Testicular Axis to Gonadotropin-releasing Hormone and Chorionic Gonadotropin during the First Week of Life
}

\author{
LEO DUNKEL, JAAKKO PERHEENTUPA, JUHA TAPANAINEN, PEKKA LEINONEN, AND \\ REIJO VIHKO \\ Children's Hospital, University of Helsinki [L.D., J.P.] and Department of Clinical Chemistry, University of Oulu \\ [J.T., P.L., R.V.], Finland
}

\begin{abstract}
Qualitative changes are known to occur in testicular steroidogenesis at birth as the testosterone peak is reached without significant elevation of basal luteinizing hormone in the 2 nd wk of life. This study was designed to evaluate testicular activity prior to these changes. Pituitary-testicular function was studied by measuring serum gonadotropins and steroids after stimulation by gonadotropin-releasing hormone (GnRH) (one intravenous injection) and human chorionic gonadotropin (hCG) (three intramuscular injections). The subjects had minor genital anomalies; their ages ranged from 2 to 6 days. All had a strong luteinizing hormone response and a weaker follicle-stimulating hormone response to GnRH stimulation. hCG induced significant increases in serum pregnenolone, 17hydroxyprogesterone, androstenedione, testosterone, and dihydrotestosterone. Serum estradiol and estrone did not change, and progesterone decreased. The results clearly show that the pituitary-testicular axis is functional neonatally. The responsiveness of the testis to $\mathrm{hCG}$ supports the assumption that the postnatal decrease of testicular steroids is due to the simultaneous disappearance of hCG from the circulation. The neonatal testis does not show any estradiol response to hCG, which is a feature typical of prepuberty. (Pediatr Res 18:1085-1087, 1984)
\end{abstract}

\section{Abbreviations}

GnRH, gonadotropin-releasing hormone

LH, luteinizing hormone

FSH, follicle-stimulating hormone

hCG, human chorionic gonadotropin

17-OHP, 17 $\alpha$-hydroxyprogesterone

DHT, dihydrotestosterone

$E_{1}$, estrone

$\mathbf{E}_{2}$, estradiol

In male infants, the relatively high concentrations of serum testosterone found on the 1st postnatal day decrease rapidly to a low level which is maintained for about $1 \mathrm{wk}$, after which a transient activation of the hypothalamic-pituitary-testicular axis

Received November 28, 1983; accepted March 23, 1984.

Requests for reprints should be addressed to Dr. L. Dunkel, Children's Hospital, SF-00290 Helsinki 29, Finland.

This study was supported by the Sigrid Juselius Foundation, the Foundation for Pediatric Research, Helsinki Finland, Ford Foundation Grant 730-0670, and the Medical Research Council of the Academy of Finland. takes place $(4,12,13,16)$. During the period of relative testicular quiescence on days 3 to 6 after birth, stimulation by $\mathrm{GnRH}$ evokes significant response in serum LH concentrations (14). It has not been known to date whether the testis could respond to LH or hCG stimulation in this period. The aim of this study was to test this as such information would be of value in understanding the regulation of testicular function. As such studies cannot be made in normal human newborns we chose those with only minor genital anomalies as subjects. They were given a GnRH test followed by a hCG test.

\section{MATERIALS AND METHODS}

Subjects. Our series consisted of 16 full-term newborn male infants with minor genital abnormalities. They were 2.25 to 6.0 days old at the beginning of the testing. Twelve had incomplete testicular descent; nine unilaterally (four testes were not palpable) and three bilaterally (all inguinal). Only one infant had a testis still not palpable at the age of 12 months but at surgery, it was found to be of normal size and consistency. Three of the other infants needed an orchidopexy at the age of $1 \mathrm{yr}$. Two infants had surgically insignificant glandular hypospadias and two had a penis shorter than mean - 2SD for gestational age (2). The Ethical Committee of the Hospital approved this study, and an informed consent was obtained from all parents.

Tests. To the release of the pituitary gonadotropins, GnRH (Relefact, Hoechst AG, F. R. G.), $3.5 \mu \mathrm{g} / \mathrm{kg}$ was injected intravenously during $1 \mathrm{~min}$ between 0830 and 1100 . One-ml specimens of peripheral venous blood were taken at $-20,0,30,60$, and $120 \mathrm{~min}$ for measurement of serum LH and FSH. Baseline steroid analyses were made from a 3-mi specimen of heparinized blood taken at $0 \mathrm{~min}$. At the end of the $\mathrm{GnRH}$ test, $1500 \mathrm{IU} / \mathrm{m}^{2}$ of hCG (Pregnyl, Organon, Oss, the Netherlands) were injected intramuscularly. This injection was repeated twice at 48 -h intervals and a second plasma sample for steroid analyses was taken $24 \mathrm{~h}$ after the last injection, i.e. 5 days after the first hCG injection. The separated serum specimens were stored at $-20^{\circ}$ C.

Methods. Serum LH and FSH were measured by a double antibody radioimmunoassay using LER-907 as standard. Highly purified FSH (LER 1801-3) and LH (LER 960), and antisera (anti-FSH batch No. 4, and anti-LH batch No. 2) were kindly donated by the National Institute of Arthritis, Diabetes, and Digestive and Kidney Diseases, National Institutes of Health. The results were transformed to IU/liter by multiplying the values of FSH (in ng LER-907/ml) by 0.0185 and the values of LH (in ng LER-907/ml) by 0.344 . The detection limits for LH and FSH were 3.4 and $0.18 \mathrm{IU} /$ liter, and the coefficients of variation were 14.4 and $12.2 \%$ interassay and 11.7 and 10.1 
intra-assay, respectively. Cross-reactivity of the $\mathrm{LH}$ antiserum with hCG was $28 \%$ at $50 \%$ binding. To ensure that hCG did not cause any errors in the determinations, it was quantified in the sera of 0.2 - to 6.0 -day-old boys with an antiserum against the $\beta$ subunit of hCG. All the concentrations after the 1 st day of life were less than $5 \mathrm{IU} /$ liter. Thus, the contribution of hCG to the $\mathrm{LH}$ results was below the detection limit in all instances.

Plasma neutral steroids were quantified as described earlier (5). After the separation of the steroid fractions on Lipidex-5000 microcolumns, each steroid was quantified by a radioimmunoassay of carefully defined specificity. Serum estradiol and estrone were also chromatographed in a Lipidex-5000 column, and then quantified by radioimmunoassay, as described earlier (7). Because of the positive skewness of the distributions, all calculations were made after logarithmic transformation; all values of curtosis/SEM and skewness/SEM were then $<2.0$. The differences between basal and stimulated hormone levels were evaluated by Student's $t$ test for paired values (11).

\section{RESULTS}

The mean basal serum levels were $25.9 \mathrm{IU} /$ liter for $\mathrm{LH}$ and $1.09 \mathrm{IU} /$ liter for FSH. All infants showed a strong LH response following GnRH stimulation; the peak occurred at $30 \mathrm{~min}$ (in one case at $60 \mathrm{~min}$ ) averaging 2 -fold the basal level (Table 1, Fig. 1). The FSH response was weaker, the peak level being on average 1.35 -fold the basal level, and it occurred equally often at 30 as at $60 \mathrm{~min}$. No correlations were found between LH and FSH levels basally or thereafter.

hCG stimulation increased the concentrations of pregnenolone, 17-OHP, androstenedione, and DHT very significantly, but there was a decrease in progesterone levels (Fig. 2); serum $\mathrm{E}_{2}$ and $\mathrm{E}_{1}$ concentrations did not change.

\section{DISCUSSION}

Our subject group was not strictly normal but it did not include any case of definite endocrine abnormality. Such cases are very rare among boys with minor abnormalities and could be expected to give a clearly abnormal dynamic test, whereas the findings in our series were homogeneous. Some boys with mild LH defi-

Table 1. Baseline (b) and maximal post-GnRH (s) serum gonadotropin levels (IU/liter), and post-hCG (s) steroid levels $(\mathrm{ng} / \mathrm{ml})$; values are means with $90 \%$ confidence levels)*

\begin{tabular}{lccl}
\hline LH & $\mathrm{b}$ & 25.9 & $(18.7-35.9)$ \\
FSH & $\mathrm{s}$ & $50.8^{a}$ & $(34.3-75.2)$ \\
Pregnenolone & $\mathrm{b}$ & 1.09 & $(0.71-1.68)$ \\
& $\mathrm{s}$ & $1.57^{b}$ & $(0.90-2.74)$ \\
Progesterone & $\mathrm{b}$ & 2.32 & $(0.96-5.57)$ \\
& $\mathrm{s}$ & $2.74^{a}$ & $(0.58-12.94)$ \\
17-OHP & $\mathrm{b}$ & 0.37 & $(0.15-0.89)$ \\
& $\mathrm{s}$ & $0.21^{b}$ & $(0.13-0.34)$ \\
Androstenedione & $\mathrm{b}$ & 0.38 & $(0.14-1.04)$ \\
& $\mathrm{s}$ & $0.97^{a}$ & $(0.56-1.69)$ \\
Dehydroepiandrosterone & $\mathrm{b}$ & 0.59 & $(0.25-1.39)$ \\
& $\mathrm{s}$ & $0.90^{a}$ & $(0.42-1.93)$ \\
Testosterone & $\mathrm{b}$ & 2.91 & $(0.59-13.25)$ \\
& $\mathrm{s}$ & 4.07 & $(0.38-36.81)$ \\
DHT & $\mathrm{b}$ & 0.27 & $(0.04-1.68)$ \\
& $\mathrm{s}$ & $2.63^{a}$ & $(1.08-6.39)$ \\
Estrone $(\mathrm{pg} / \mathrm{ml})$ & $\mathrm{b}$ & 0.44 & $(0.22-0.89)$ \\
& $\mathrm{s}$ & $1.04^{a}$ & $(0.56-2.03)$ \\
Estradiol $(\mathrm{pg} / \mathrm{ml})$ & $\mathrm{b}$ & 15.6 & $(8.1-30.1)$ \\
& $\mathrm{s}$ & 13.6 & $(7.1-25.8)$ \\
& $\mathrm{b}$ & 17.0 & $(7.8-36.8)$ \\
\hline
\end{tabular}

* Significance of the difference between baseline and stimulated values: ${ }^{a} p<0.001 ;{ }^{b} p<0.01$.

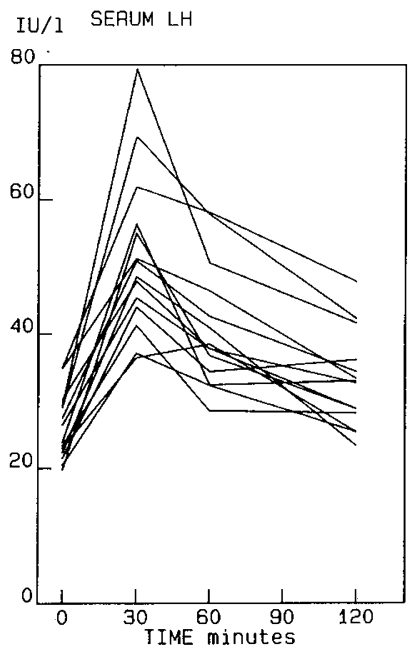

IU/I SERUM FSH

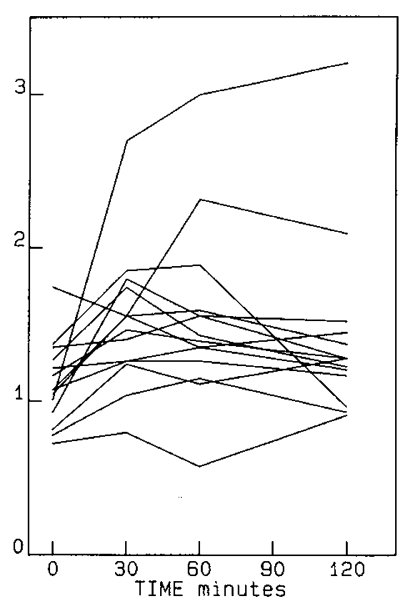

Fig. 1. Individual gonadotropin responses to $\mathrm{GnRH}$
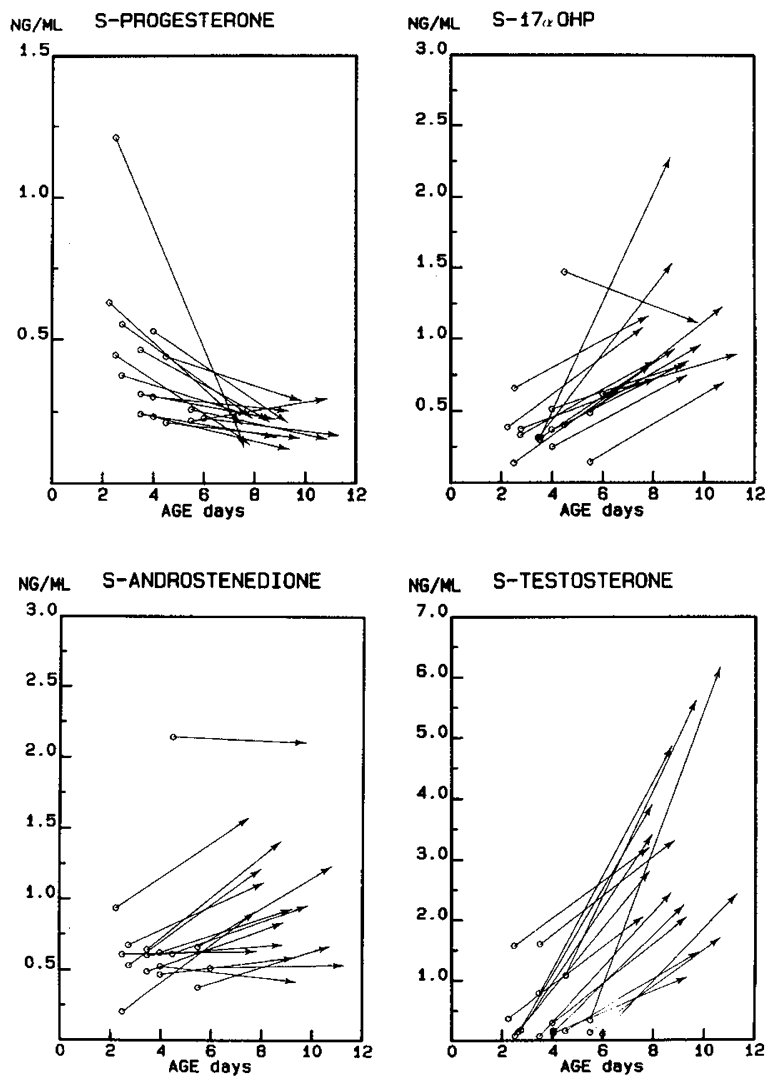

Fig. 2. Steroid responses to hCG stimulation plotted against age. The basal values are indicated by open circles; the stimulated values are indicated by arrowheads.

ciency may, however, have been included since this is frequently associated with incomplete testicular descent (6). The concentrations of FSH in the present study were in agreement with earlier reports whereas the $\mathrm{LH}$ levels were higher, presumably due to methodological differences $(1,14,15)$. The response pattern of the gonadotropins to $\mathrm{GnRH}$ was similar to that described in earlier studies $(1,14)$. The low pituitary-gonadal activity during the third trimester of gestation is therefore probably due to the inhibitory effects of the placental steroids, and this continues postnatally during the 1 st wk of life (12). It is not known what happens to the hypothalamic GnRH-secreting capacity during this period, but the pituitary at least is responsive neonatally to exogenous GnRH stimulus. 
Steroidogenic response to hCG has not been described previously in this age group. Our results clearly indicate that the testis is responsive to hCG in the 1st postnatal wk. This supports the assumption that the spontaneous decrease of the testicular steroids is due to the simultaneous disappearance of hCG from the circulation of the neonate $(12,16)$. The significant increases found in serum pregnenolone, 17-OHP, androstenedione, testosterone, and DHT after hCG stimulation show that in the neonate as well as in the adult these steroids originate partly in the testis $(3,8,9)$. In contrast to the pubertal $(10,15)$ and the adult testis $(3,8), \mathrm{E}_{2}$ did not increase after hCG stimulation. In the adult testis, the hCG-induced increase in 17-OHP has been associated with the intratesticular inhibition of $\mathrm{C}_{17-20}$-desmolase by $\mathrm{E}_{2}$ (3, 8). In prepubertal boys, serum $E_{2}$ and 17-OHP do not increase after hCG stimulation, which is possibly due to the low basal levels of the gonadotropins (15). The reason for the neonatal testis responding to hCG with an increase in serum 17-OHP but with none in serum $E_{2}$ is not known. One possibility is that testicular $E_{2}$ production in the neonate is already maximally stimulated by placental hCG. This is supported by the fact that circulating $\mathrm{E}_{2}$ concentrations in our patients were moderately high (Table 1).

The elimination of placental steroids is likely the main factor responsible for the transient activation of the hypothalamicpituitary testicular axis in the first few months of life. Serum concentrations of pregnenolone, progesterone, and 17-OHP decrease rapidly during the first postnatal day, indicating their placental origin. In contrast testosterone concentrations increase markedly (12). It appears possible that those placental steroids have a suppressive effect on the testis, and their elimination leads to an activation of testosterone production by hCG, which still circulates in high concentrations at birth (16). After the 1st day, the hCG concentrations and, consequently, the testosterone concentrations decrease.

We conclude therefore that the pituitary-testicular axis is functional during the first postnatal week and that spontaneous activation of it does not take place at this time, probably due to the inhibitory effects at the hypothalamic level of the persisting circulating placental steroids.

\section{REFERENCES}

1. Delitala G, Meloni T, Masala A, Alagna S, Devilla L, Corti R 1978 Effect of LRH on gonadotropin secretion in newborn male infants. J Clin Endocrinol

\section{Metab 46:689}

2. Feldman KW, Smith DW 1975 Fetal phallic growth and penile standards for newborn male infants. J Pediatr 86:395

3. Forest MG, Lecoq A, Saez JM 1979 Kinetics of human chorionic gonadotropin induced steroidogenic response of human testis. II. Plasma $17 \alpha$-hydroxyprogesterone, $\Delta^{4}$-androstenedione, estrone and $17 \beta$-estradiol: evidence for the action of human chorionic gonadotropin on intermediate enzymes implicated in steroid biosynthesis. J Clin Endocrinol Metab 49:284

4. Forest MG, de Peretti E, Bertrand J 1980 Testicular and adrenal androgens and their binding to plasma proteins in the perinatal period: developmental patterns of plasma testosterone, $\Delta^{4}$-androstenedione, dehydroepiandrosterone and its sulfate in premature and small for date infants as compared with that of full-term infants. J Steroid Biochem 12:25

5. Hammond GL, Ruokonen A, Kontturi M, Koskela E, Vihko R 1977 The simultaneous radioimmunoassay of seven steroids in human spermatic and peripheral venous blood. J Clin Endocrinol Metab 45:16

6. Job JC, Garnier PE, Chaussain JL, Toublanc JE, Canlorbe P 1974 Effect of synthetic luteinizing hormone-releasing hormone on the release of gonadotropins in hypophyseo-gonadal disorders of children and adolescents. $J$ Pediatr 84:371

7. Leinonen P 1980 Estrone and estradiol concentrations in the testis and spermatic and peripheral venous blood of elderly men: the influence of estrogen treatment. J Steroid Biochem 13:737

8. Martikainen H, Huhtaniemi I, Vihko R 1980 Response of peripheral serum sex steroids and some of their precursors to a single injection of hCG in adult men. Clin Endocrinol (Oxf) 13:157

9. Padron RS, Wischusen J, Hudson B, Burger HG, de Kretser DM 1980 Prolonged biphasic response of plasma testosterone to single intramuscular injections of human chorionic gonadotropin. J Clin Endocrinol Metab 50:1100

10. Roth JC, Grumbach MM, Kaplan SL 1973 Effect of synthetic luteinizing hormone-releasing factor on serum testosterone and gonadotropins in prepubertal, pubertal and adult males. J Clin Endocrinol Metab 37:680

11. Snedecor GW, Cochran WG 1980 Statistical Methods, pp 106-1 19. The Iowa State University Press, Ames.

12. Tapanainen J 1983 Hormonal changes during the perinatal period: serum testosterone, some of its precursors, and FSH and prolactin in preterm and fullterm male infant cord blood during the first week of life. J Steroid Biochem 18:13

13. Tapanainen J, Kellokumpu-Lehtinen P, Pelliniemi L, Huhtaniemi I 1981 Agerelated changes in endogenous steroids of human fetal testis during early and midpregnancy. J Clin Endocrinol Metab 52:98

14. Tapanainen J, Koivisto M, Huhtaniemi I, Vihko R 1982 Effect of gonadotropin-releasing hormone on pituitary-gonadal function of male infants during the first year of life. J Clin Endocrinol Metab 55:689

15. Tapanainen J, Martikainen H, Dunkel L, Perheentupa J, Vihko R 1983 Steroidogenic response to a single injection of hCG in pre-and early pubertal cryptorchid boys. Clin Endocrinol (Oxf) 18:355

16. Winter JSD, Fairman C, Hobson WC, Prasad AV, Reyes FI 1975 Pituitarygonadal relations in infancy. I. Patterns of serum gonadotropin concentrations from birth to four years of age in man and chimpanzee. $\mathrm{J}$ Clin Endocrinol Metab 40:545

17. Winter JSD, Fairman C, Reyes FI 1981 Sexual endocrinology of fetal and perinatal life. In: Edwards RG, Austin CR (eds) Mechanism of Sex Differentation in Animals and Man. Academic Press, London 